104 Left History 6.2

\title{
Shooting Imperialism: Three Documentaries by Julian Samuel
}

The Raft of the Medusa: Five Voices on Colonies, Nations and Histories (1993, 99 minutes)

Into the European Mirror (1994, 56 minutes)

City of the Dead and the World Exhibitions (1995, 76 minutes)

In the recent past much has been written about colonialism, imperialism, and postcolonialism. Inside the academy, a number of scholars have explored the complex relations of power, exploitation, and dominance, as well as the related issues of longing, fantasy, and desire for the "other," that fuelled the expansion of European colonization into the Americas, Africa, and Asia. As well as seeking to understand the role played by "conquerors," this scholarship has also drawn our attention to the roles of indigenous peoples in colonial projects: their resistance, complicity, and negotiation of structures both material and discursive and the effects of imperialism on their societies. Postcolonial theory has played no small role in revitalizing an area previously devoted to discussions of imperial political strategy and decisions undertaken at the "centre"; in fact, much recent work has challenged scholars to reconsider their notions of "margin" and "centre." Some of this research has also found its way into undergraduate and graduate curricula, being deployed as world history courses or as courses that focus on various imperialisms. ${ }^{1}$

In this proliferation of print on the topic, Julian Samuel's work challenges us to consider the possibilities and limitations of the place of film as a medium to explore these issues. As an historian who, by training and by practice, has spent much of her time dealing with written texts, I was curious to see how documentary film might deal with the histories of colonialism and imperialism. What, I wondered, were the possibilities offered by film and what were the limitations? How might the medium of film, with its ability to shift the viewer from one speaker, topic, and national boundary to another by juxtaposition or rapid movement - not to mention its use of visual material alter or challenge our ability to explore these histories? And what place, 1 wondered, might these films have for classroom use?

Samuel, a self-described Christian-Pakestani-Québeçois-Montrealer, has produced these films and has also published a number of books on these and related topics. ${ }^{2}$ The three documentaries reviewed here are generally about Islam and its relationship to the West, although other kinds of colonial relationships and contexts are also discussed: central Africa, Hong Kong, the Caribbean, and India. All three feature a cast of commentators who have either 
written about and in many cases, directly experienced colonial/postcolonial conditions in these contexts. ${ }^{3}$ While there are multiple overlapping themes treated by these films (they are, after all, meant to be a trilogy), each one has a slightly different focus. The Raft of the Medusa looks at the development of the "Orient" by the West as an historical category and strategy for viewing and producing knowledge about Islamic countries. Throughout his treatment of this theme Samuel intersperses interviews with Marlene Nourbese Philips on black history, both African and Caribbean; with Sara Suleri on the 1947 partition of India and Pakistan and Indian independence; and with Ackbar Abbas on the colonial/postcolonial status of Hong Kong. In Into the European Mirror, much of which was shot at the Alhambra, Samuel continues these themes but shifts his focus to examine the notion of "borders" and their establishment by nationstates, using Spain's late fifteenth-century symbolic and literal expulsion of its Muslim and Jewish populations, and Palestine in the twentieth century, as examples of such processes. The third film, City of the Dead and the World Exhibitions, takes the viewer to Cairo where a range of topics past and present are discussed: gender distinctions and architecture, the imperialist projects of world exhibitions and their role in shaping the "Orient" for the West, the growth of Islamic religious fundamentalism, and the role of the Egyptian state.

Samuel uses a montage of interviews through much of the films, moving back and forth between the various interviewees. At times - but only occasionally - the viewer is made aware of his presence. There is, though, always an implicit dialogue between his subjects, whether they hold similar or different perspectives on the same subject. And, lest this use of "talking heads" may sound somewhat dull, I would argue that it is anything but that. For one, Samuel's subjects are extremely articulate and passionate about their topics, whether they are addressing the machinations of Egyptian governments or the West's excision of Islam from its historical memory. As well, the films are visually arresting, as Samuel makes extensive use of techniques such as split screens (with a small, framed "head" in one corner surrounded by a larger image), particular settings (such as the Alhambra or the Pyramids), or various kinds of montages that expand, contract, and disappear. Samuel draws upon the wealth of images that have been and continue to be produced by imperialism: Cairo's architecture; documentary footage of imperial spectacles; and the silks and other luxury items consumed in Hong Kong's luxury boutiques (the boutiques themselves also feature as spectacle of consumption). Furthermore, the paintings used by Samuel to frame much of his work - many of them taken from nineteenth-century "Orientalist" painters - also point to the sheer excesses of imperialist imagery, the proliferation of such visual materials in the West, over the course of the nineteenth and twentieth centuries. The constant flow of these images, the fact that they are so very conspicuous and figure so prominently in the films, is a device that also underscores their power. Paintings of odalisques or shots of the so-called "Islamic city" are not simply 
visually arresting backdrops to the interviews: to paraphrase Edward Said, they have been the texts into which geopolitical awareness has been distributed. ${ }^{4}$

There are many themes that unite this trilogy, although each film has a slightly different emphasis. One of the most compelling - and one that is clearly stated in Raft and Into the European Mirror - is that of the dominance of Eurocentric historical narratives, particularly vis-à-vis Islam. A particular and pernicious historical teleology and amnesia, many of these commentators argue, has shaped Western history. Western memory has failed in a number of ways, we are told, as its focus and periodization have been shaped not by purely "scholarly" academic practice but rather by the epistemological work of imperialism. Conventional narratives that privilege the Renaissance by seeing it as the emergence from "darkness" into "light" do great damage to the history of Islam and the Arab world, as the centuries known to the West as "medieval" were, in fact, ones of significant scientific and cultural advance in Islamic societies. The West's definition of modernity, too, has not only excluded the East, it has also depended on notions of the East as existing outside the temporality of "modern times." As the interviews conducted with Thierry Hentsch at the Alhambra point out, the very notion of "historical time" is a conflicted and power-laden one. This is not a new insight - feminist scholars, for one, have been making this argument for some time - but it is one worth repeating, particularly in the classroom.

Samuel's interview of architectural scholar Janet Abu-Lughod was, for me, extremely illuminating. Abu-Lughod's work examines the architecture of cities in Algeria, Morocco, and Egypt, cities that have often been a favourite Western trope for knowledge about "Middle Eastern" societies, a trope in which architectural design (the use of walled courtyards, for example) has been linked to the sequestration of women. During the course of her research, she began to realize that the descriptions of "Islamic" cities she was using were generalizations of only two or three cities that had undergone French occupation; the French had constructed them according to their notions of a "medieval Orient." Walled cities such as Medina, in which the "native" population dwelled (a popular image in both novels and movies), were in fact a creation of the colonial power, material testament to its desire to demarcate the boundaries between "West" and "East"; they were not, as has been argued, a sign of respect for Muslim culture and social organization. Not only were French residents banned from living in the Muslim quarters, Abu-Lughod points out that the fortified walls surrounding these areas could be used to contain the indigenous population living within them.

The documentaries also seek to explore not just the "construction" of an imagined and fantasy-ridden "Orient" but they also seek to reverse these mirror images of East and explore what the "West" meant to it. For many albeit not all - of Samuel's interviewees, the coming of the Western colonialism meant a violent rupture with rich and complex pasts; 
simultaneously, other kinds of narratives were created that, as we have seen, posed significant cultural, social, economic, and political problems for colonized countries. Those who spoke of borders and frontiers argue that there are no - nor were there ever - "natural" frontiers or nations: rather, what we have been left with are the legacies of imperial relations and the power struggles embedded within them, whether we speak of fifteenth-century Spain or 1990s Bosnia. But some of the interviewees also speak of the permeability of national borders that, despite official attempts to make inviolable, increasingly escape the nation-state's control. Such a point is, I think, best personified in the testimony of Medicins Sans Frontiers doctor Chris Giannou. As he moves from one war zone to another, from Beruit to Somalia, Cambodia, and Bosnia, Giannou (who himself has taken numerous physical risks) points out that certain commodities and ideologies - drugs, arms, and religious doctrines - are no respector of such boundaries. Such properties circulate from one country to another, often without ideological restraints, creating unimaginable havoc and horror in the process. In the late twentieth century, Giannou argues, "frontiers" in many contexts have become opportunities for arms bazaars. But Giannou also describes the "moral frontier" that he himself cannot leave and that he has seen exemplified in the many refugee camps in which he has worked. This frontier of human dignity, he argues, was demonstrated in the Palestinian camp of Shatila by Christians, Muslims, and Lebanese. It is one that transcends nation and religion and allows human beings to overcome starvation, bombardment, and brutality.

These documentaries, though, offer no comfort for those who want uncomplicated or seamless narratives of imperialism. Many of Samuel's interviewees insist that we cannot replace the Western metanarratives of the past with new ones that rely on the trope of pristine indigenous cultures being irrevocably corrupted by "evil empires." Subaltern nationalisms themselves have often been initiated by imperialist structures and are thus, it is argued, to some degree implicated and embedded in imperialism. The 1857 Indian Mutiny, Sara Suleri argues in Raft, sparked Indian nationalism and in her eyes, India's nineteenth-century colonial experiences were thus automatically modernizing. In the same documentary, Ackbar Abbas points out that the case of Hong Kong confounds our paradigms of imperialist expansion and indigenous peoples' suppression. Hong Kong, he argues, was not a "nation" prior to the British arrival; there is no "history"of Hong Kong as a separate entity, only barren rock overlaid with the residue of colonialism. Therefore, according to Abbas, there can be no position outside "colonialism," only resistance from the inside. And, while Hong Kong will pass from one imperial power to another and thus be politically subordinate, it has already achieved superiority over China in technology and communications and therefore inhabits two different periods simultaneously. ${ }^{5}$ Unlike India in 1947, a "postcolonial" situation has been attained without decolonization and in fact 
precedes a new period of colonialism; this is a narrative that has, in Ackbar's words, been "garbled." The advanced state of Hong Kong's economy means that a subaltern model such as India's will simply not fit: historical specificity must be substituted for totalizing theory.

Samuel's interviewees also remind us that we need to move beyond the binaries of "West" and "Other" in seeking to both understand and dismantle imperialist projects. While beginning with the framework of "West" and "Orient" set out by Said, Raft of the Medusa, in particular, also attempts to dismantle these categories. Suleri points to the "anxiety" of the colonizer for whom the material benefits of imperialism were juxtaposed against the psychic costs. Her particular example is that of Rudyard Kipling: born in Lahore, his first language was Hindi and his primary adult contact was with his Indian ayah. Kipling's removal to an English boarding school, Suleri argues, was a trauma from which he, like so many other Anglo-Indian children, did not recover. To Kipling and his peers India, not Britain, was "home." Suleri urges us to renounce the rhetoric of us and them, calling it a dangerous way of maintaining binaries. She also argues that we move away from biologicallyinflected ways of seeing race, gender, and cultural differences, a strategy that includes abandoning notions of "appropriation of voice." But for Suleri multiculturalism is not the answer, as she believes this position simply reinforces rigid dichotomies: it is both the commonality of human experiences and the differences created by human cultures that should inform our inquiries.

Nourbese Philips follows Suleri with the observation that, notwithstanding David Livingstone's role in imperialism in Africa, Livingstone occupied a more complex position than simply that of the "white European/British male." He came from a poor Scottish background (an observation that reminds us of the need to consider the specifics of colonizers' backgrounds) and Livingstone often preferred the company of Africans to that of his peers - albeit that of Africans with little European contact. In discussing Salman Rushdie, Amin Maalouf speaks of the need for multiple identities: "I think that exclusive belongings are a terrible thing and I refuse them." Near the end of Raft, Maalouf declares that "l'centre, c'est l'homme" who has the right to borrow from all religions, beliefs, and nations. "I refuse to belong to any nation, but I respect those who claim multiple nations ... and this is the future."

Samuel also engages with the issue of religion, both religion as Christian misapprehensions of Islam but also as the complicated relations of Islam and Judaism, both to Christianity and to each other. Into the European Mirror in particular has much to say about the intertwining of religion and imperialism. Not only did Spanish Catholicism, according to Thierry Hentsch, expel both the "real bodies" of first Jews and then Muslims after seven centuries of peaceful co-existence, the dominant narratives of European history subsequently expelled them from its purview. Both literally and symbolically, 
then, these "Others" were deemed unnecessary to Spain which reconstituted itself as a nation of singular religious identity, a homogenous state that, as it "cleansed" itself and reified its own borders, was also embarking upon imperial expansion overseas. Four centuries later, these "Others" reappear in a rather different relationship, one still inflected by imperialism but because of historical contingencies configured in a different manner. The construction of a Jewish state in Palestine, according to Hentsch, also depended upon European powers' exclusion of Arabs from that state's very definition. In his 1919 letter to British Opposition leader David Lloyd George, Arthur Balfour admitted that Arabs would be left out of Palestine; however, such an exclusion was justifiable because of Europeans' historical tie to Judaism and "this part of the world." Europeans thus felt justified in this imperial project because, in Hentsch's view, they recognized themselves in it through the Bible - not because they recognized the rights of Jews to a home-land. Giannou also argues that a mixture of European culpability and guilt helped found the state of Israel. Having refused to save Jews from the Nazis in the 1930s and during the Second World War, European powers attempted to redeem themselves by creating a Jewish state and, in the process, also made the Palestinians the victims of victims, a scapegoat onto whose shoulders European anti-Semitism could be displaced. Yet another arena of religion and the state is addressed in City of the Dead, with its explicit discussion of the roles of the Egyptian and Algerian governments in creating a "fundamentalist" crisis by their manipulations of their respective publics.

Samuel also links aspects of culture - language, symbol, image, metaphor, and narrative - to the material aspects of imperial expansion and resistance (although he is less interested in tracing the economic roots of colonialism). The two are intertwined in a number of ways. Chris Giannou, for example, feels that his own body has been an allegory, mirroring the "pathologies" of the societies in which he has worked. In Cambodia Giannou and his colleagues performed numerous amputations on villagers blown apart by land mines, operations led by "foreign doctors" since the senior ranks of the medical profession had been decimated by the Khmer Rouge. Giannou thus sees a parallel between the maiming of his patients and Pol Pot's own "amputation" of Cambodian society. As well, Samuel's cinematic effects (his use of documentary footage of French police executing Algerian nationalists during the $1950 \mathrm{~s}$, for example, that underlies one of his interviews) reminds us that constructing and disciplining the "Other" has been bound up with deportations, executions, and massacres. The "planned epistemic violence" of imperialism was also "backed up by the planned institutional violence of armies and law courts, prisons and state machinery." 6

Yet cultural symbolism and imagery are important not only for their ability to illuminate power relations: they can also be used to explore cultural differences. In addition to Abu-Lughod's work on colonial architecture, the 
documentaries (particularly Into the European Mirror) examine religious distinctions as expressed in architectural structures. A number of Samuel's interviewees argue that Christianity (specifically Catholicism) and Islam have organized their spaces of worship quite differently, especially their use of light. In European cathedrals of the Middle Ages, light was deployed in a very directed and deliberate manner, designed to penetrate into otherwise dark and gloomy interiors as piercing shafts from above. In the Arab world, though, light is used to illuminate the entire courtyard of the mosque and to encompass all worshippers; the sky is an integral part of the religious structure. Moreover, by setting discussions of the historical expulsion of Islam from the West in the Alhambra, Samuel reinforces not just the liminality of that particular spot but also, I believe, asks us to rethink our notions of how we recognize claims of ownership of locations, texts, and people by either "East" or "West."

Much of what is discussed in these documentaries will not, of course, be entirely new - at least in its theoretical and conceptual forms - to scholars of colonial histories or postcolonial theories. And those historians who work in the fields covered by these films may disagree with the specificities of the arguments made in these documentaries. Yet the format in which these ideas are presented is a particularly compelling and intriguing one. Film allows a constant mingling of past and present, a shifting of these boundaries that is often difficult to achieve in print. While some might find this undermining of the historian's carefully-guarded temporal boundaries a problem, it strikes me that, particularly for teaching, it is a salutary reminder that we cannot consider imperialism as a completed project. In that respect, too, I think these documentaries (and especially Raft of the Medusa) could be of great help in introducing students to these issues, particularly since each one stands well on its own. Samuel's work could also help facilitate discussions of how we might conceive and teach beyond the nation-state, an issue recently raised by Victoria Heftler in the pages of this journal, since he is interested in exploring not just differences between East and West but also the connections that bind the two and the attempts of those who guard national borders to deny these links. ${ }^{7}$

Perhaps the one and, to my mind, glaring absence from these documentaries is that of gender as an analytic category and a set of relations that both shaped and was shaped by imperialism. Although we hear about colonial architecture and gender relations in North Africa, and gender relations are implicit in much of Samuel's visual materials (the masculinist military power of the state, or the figures of "Oriental" women in the paintings), the interviews tell us little - at least explicitly - about the different impact of imperialism on colonized men and women, or the recurrence of gendered imagery and symbolism in both imperial and subaltern discourses. The inattention to gender is particularly striking in discussions of modernity, since over the nineteenth and twentieth centuries the "veiled woman" has been a recurring trope for "Eastern backwardness" in comparison to Western 
modernity. ${ }^{8}$ Moreover, although I realize that this is not Samuel's project, I suggest that, just as we cannot generalize about "the East," nor should we be too hasty to create a monolithic "West" since in these documentaries the "West" is so often really Europe; North and South America, with their own (and also highly differentiated) trajectories of imperialism are absent.

That being said, though, Samuel brings considerable skill, creativity, and political acuity to this area of historical research. These films not only remind us that their themes are by no means "over and done with" but they also suggest new ways of imagining - despite the difficulties involved - a more truly "postcolonial" future.

\section{Cecilia Morgan}

Ontario Institute for Studies in Education / University of Toronto

I See, for example, Monica M. van Beusekom et. al., "Teaching Radical History: Empire and Encounter III," Radical History Review 71 (Spring 1988), 133-81.

2 For this description of Samuel, see Elaine Kalman Naves, "Gadfly on our body politic," Montreal Gazette, 5 July, 1997 (a review of Samuel's Passage to Lahore [Mercury Press, 1995]).

${ }^{3}$ The interviewees for Raft are Marlene Nourbese Philips, Amin Maalouf, Thierry Hentsch, Sara Suleri, Ackbar Abbas; for Into the European Mirror Homi Bhabha, Chris Giannou, Hentsch, and Rana Kabbani; and for City of the Dead Janet Abu-Lughod, Akbar S. Ahmad, Hussein Ahmed Amin, Edwar Al-Kharrat, Max Rodenbeck, and Timothy Mitchell.

${ }^{4}$ Edward Said, Orientalism (New York 1978), 3.

5 The documentary was made prior to the British departure from Hong Hong.

${ }^{6}$ Anne McClintock, Imperial Leather: Race, Gender and Sexuality in the Colonial Contest (London \& New York 1995), 16.

7 Victoria Heftler, "The Future of the Subaltern Past: Toward a Cosmopolitan "History from Below,"' Left History 5.1 (Spring 1997), 65-84.

${ }^{8}$ The literature on gender and imperialism is quite large but see McClintock, Imperial Leather; also Reina Lewis, Gendering Orientalism: Race, Femininity, and Representation (London \& New York 1996); and Ruth Roach Pierson and Nupur Chaudhuri, with the assistance of Beth McAuley, Nation, Empire, Colony: Historicizing Gender and Race (Bloomington, Ind. 1998). 